\title{
Assessment of Volatile Chemical Composition of the Essential Oil of Jatropha ribifolia (Pohl) Baill by HS-SPME-GC-MS Using Different Fibers
}

\author{
Celia Eliane de Lara da Silva, ${ }^{1}$ Willian Ferreira da Costa, ${ }^{2}$ Sandro Minguzzi, ${ }^{1}$ \\ Rogério Cesar de Lara da Silva, ${ }^{1}$ and Euclésio Simionatto ${ }^{1}$ \\ ${ }^{1}$ Centro de Pesquisas e Tecnologia em Recursos Naturais (CPTREN), Pós-Gradução em Recursos Naturais (PGRN), \\ Departamento de Química, Universidade Estadual de Mato Grosso do Sul (UEMS), Rua Emílio Mascolli, 275, \\ 79950-000 Naviraí, MS, Brazil \\ ${ }^{2}$ Complexos e Centrais de Apoio a Pesquisa (COMCAP), Departamento de Química, Universidade Estadual de Maringá (UEM), \\ Avenida Colombo, 5790, Jd Universitário, 87020-900 Maringá, PR, Brazil
}

Correspondence should be addressed to Rogério Cesar de Lara da Silva; rcsilva@uems.br

Received 9 May 2013; Revised 6 August 2013; Accepted 7 August 2013

Academic Editor: Mohamed Abdel-Rehim

Copyright (C) 2013 Celia Eliane de Lara da Silva et al. This is an open access article distributed under the Creative Commons Attribution License, which permits unrestricted use, distribution, and reproduction in any medium, provided the original work is properly cited.

\begin{abstract}
The chemical composition of essential oil and volatile obtained from the roots of Jatropha ribifolia (Pohl) Baill was performed in this work. The Clevenger extractor was utilized in hydrodistillation of oil and chemical composition determined by gas chromatography coupled with mass spectrometry detector (GC-MS). The identification of compounds was confirmed by retention index (Kovats index) obtained from a series of straight chain alkanes $\left(\mathrm{C}_{7}-\mathrm{C}_{30}\right)$ and by comparison with NIST and ADAMS library. A total of 61 compounds were identified in essential oil by GC-MS. The extraction of volatile was performed also by the use of the solid phase microextraction (SPME) with four different fibers. The essential oil extraction was extremely rapid (15 s) to avoid saturation of the fiber and the MS detector. The majority of the composition of essential oil is the terpenes: $\beta$-pinene (major compound 9.16\%), $\beta$-vatirene (8.34\%), $\alpha$-gurjunene (6.98\%), $\alpha$-pinene (6.35\%), camphene (4.34\%), tricyclene (3.79\%) and dehydro aromadendrene $(3.52 \%)$ it and aldehydes and alcohols. Through the SPME it was possible to determine the nine volatile compounds not identified in oil 2,3,4-trimethyl-2-cyclopenten-1-one, $\alpha$-phellandrene, 3-carene, trans- $p$-mentha-2,8-dienol, pinocamphone, $\mathrm{D}$-verbenon, 1,3,3trimethyl-2-(2-methyl-cyclopropyl)-cyclohexene, 2,4-diisocyanato-1-methylbenzene, and (6-hydroxymethyl-2,3-dimethylehenyl) methanol.
\end{abstract}

\section{Introduction}

Jatropha ribifolia (Pohl) Baill. is ember of Euphorbiaceae species found in the semiarid region of northeastern of Brazil [1] and more recently in southeastern [2]. The genus Jatropha is constituted of more than 150 species these are the most common in the semiarid region, the Jatropha mollissima (Pohl) Baill, J. mutabilis (Pohl) Baill and J. ribifolia (Pohl) Baill [3]. Other species such as J. gossypifolia L. and J. curcas
L. are found in Brazilian territory and have socioeconomic, medicinal, and ornamental importance [1].

The species J. curcas can be utilized in biodiesel production to diesel engines [4] and have been targeting very research with catalyst various $[5,6]$. The J. gossypifolia L. is a plant that can present toxicity but has been used in popular medicine in the treatment of several diseases [7]; however, some compounds may exhibit hepatic toxicity $[7,8]$. 
Many terpene compounds were isolated from the species of Jatropha with respect to new chemical structures and medicinal values. These terpenes can exhibit cytotoxic, antitumor, and antimicrobial activities in vitro, such as jatrophone, spruceanol, and jatrophatrione view activity against tumor cells $[9,10]$. The compounds isolated from are obtained from organic extract such as from bark, stem and root. Some of the terpenes are also isolates the composition of the oil obtained from the fruit. However, the composition of essential oils to volatile terpenes of Jatropha species has not been shown.

J. ribifolia is aromatic species found in southeastern region also known as "minâncora do campo." Fernandes et al. [2] newly studying J. ribifolia roots, the compounds jatrophone, and cyperenoic acid were isolated from the hexanic extract and characterized by spectroscopic techniques (NMR of ${ }^{1} \mathrm{H},{ }^{13} \mathrm{C}$, and IR). The in vitro antiproliferative activity of jatrophone showed selectivity in a concentrationdependent way with Total Inhibition Growth (TGI) of glioma $0.57 \mu \mathrm{g} \mathrm{mL}^{-1}$ (U251), breast cancer $9.2 \mu \mathrm{g} \mathrm{mL}^{-1}$ (MCF-7), adriamycin-resistant ovarian cancer $0.96 \mu \mathrm{g} \mathrm{mL}^{-1}$ (NCIADR/RES), kidney $4.2 \mu \mathrm{g} \mathrm{mL}^{-1}$ (786-0), prostate cancer $8.4 \mu \mathrm{g} \mathrm{mL}^{-1}$ (PC-3), colon cancer $16.1 \mu \mathrm{g} \mathrm{mL}^{-1}$ (HT29), and leukemia $0.21 \mu \mathrm{g} \mathrm{mL}^{-1}$ (K-562).

Extraction of volatile compounds of oil can be performed by purge-trap [11], solid phase extraction (SPE) [12], liquidliquid extraction (LLE) $[13,14]$, microwave-assisted hydrodistillation (MAHD) $[15,16]$, supercritical fluid extraction (SFE) [17], solid phase microextraction (SPME) [18, 19], and by Clevenger extractor [20], among others.

SPME is a technique that has been applied to extraction and concentration of large variety of organic compounds $[21,22]$ from several types of matrixes such as water [23], air [24], soil [25], volatile components in foods [26, 27], essential oil [18], and biological matrix [28]. Direct determination of analytes through the SPME coupling with other techniques have also been developed [23, 29, 30]. SPME consists of sorbent or adsorbent materials such as polydimethylsiloxane (PDMS), divinylbenzene (DVB), Carbowax $(\mathrm{CW})$, and Carboxen (CAR) dispersed over a silica fiber [22]. In the extraction of volatile compounds it is not necessary to use solvent facilitating the preparation and sample analysis.

This work shows the volatile compounds extraction from essential oil obtained of roots the J. ribifolia (Pohl) Baill by using the headspace sampling by SPME with different fiber with analyses by mass spectrometry. Chromatography profile obtained by fibers was compared with the chromatography profile of oil direct injection in the same conditions.

\section{Material and Methods}

2.1. Plant Material. Jatropha ribifolia (Pohl) Bail. roots were collected $(3 \mathrm{Kg})$ in region of grasslands near Navirai-MS city and transported to the organic chemistry laboratory of UEMS-Naviraí. Voucher specimens (JR 0206) have been deposited at the Herbarium of State University of Mato Grosso do Sul (unit Naviraí). The roots were washed in running water to remove earth and dried for 3 hours at room temperature. After mechanical mill was processed and placed in balloon $5 \mathrm{~L}$ and essential oil extract with Clevenger extractor apparatus until the exhaustive extraction. The essential oil collected was packaged in glass bottles own, sealed, and stored in the dark for later analysis.

2.2. Instrumentation. The chromatographic analyses were carried out using a Thermo-Finigan Gas Chromatograph (Focus DSQ II), equipped with mass spectrometry detector, and a split/splitless injector. A fiber holder for manual use was purchased from Supelco (Bellefont). SPME fibers were also from Supelco and coated with four different films: polydimethylsiloxane (PDMS) $100 \mu \mathrm{m}$, polyacrylate (PA) $85 \mu \mathrm{m}$, polydimethylsiloxane/divinylbenzene (PDMS/DVB) $65 \mu \mathrm{m}$ and a Carbowax/DVB (CW/DVB) $85 \mu \mathrm{m}$. All fibers were conditioned in the hot injector of the gas chromatograph according to instructions provided by the supplier.

2.3. Chromatographic Conditions. Analyses were performed on a gas chromatograph coupled to mass spectrometry (GCMS Thermo-Finnigan, Focus DSQ II), with a quadrupole mass analyzer, electron impact ionization $(70 \mathrm{eV})$, and autosampler model Triplus. The separation of essential oil and volatile was carried out using a DB-5 capillary column $(30 \mathrm{~m} \times 0.25 \mathrm{~mm}$ I.D. $\times 0.25 \mu \mathrm{m}$ film thickness) with $5 \%$ phenyl-methylpolysiloxane. Analytical 5.0 grade helium was used as carrier gas at a flow rate of $1.2 \mathrm{~mL} \mathrm{~min}^{-1}$. The inlet was operated in the splitless mode with splitless time of 5.0 minute for extraction of volatile by SPME fiber and operated in the split mode with injection volume of $2.0 \mu \mathrm{L}$ the oil diluted in ethyl acetate. The GC temperature program used was $40^{\circ} \mathrm{C}(1 \mathrm{~min})$ and $4^{\circ} \mathrm{C} \mathrm{min}{ }^{-1}$ up to $280^{\circ} \mathrm{C}$. The injector, ionization source, and transfer line temperatures were set at 230,250 , and $280^{\circ} \mathrm{C}$, respectively. In the TIC mode operation the mass ranged from 50 to $500 \mathrm{amu}$. Date acquisition was performed by Software Xcalibur 1.4 SR1. Data analysis was performed by NIST MS Search 2.0 library.

2.4. HS-SPME Extraction Procedure. The extraction was performed in headspace static mode (HS) with all fibers SPME. In addition, to minimize background signals, the fibers are heated in the GC-MS inlet for 5 minutes before each sampling in HS-SPME. Fifty microliters of essential oil were collected and addiction in vials $(10 \mathrm{~mL})$ for extraction by SPME enclosed on septum sealed, in laboratory at $25^{\circ} \mathrm{C}$. The fibers were exposed by $15 \mathrm{~s}$ in headspace to volatile extraction to avoid saturation of the fiber coating. The SPME fiber was exposed in the GC-MS injector for $5 \mathrm{~min}$ for total desorption of analytes. None carryover was determined to fibers. The dates were collected with Xcalibur software. To analyze the oil pure $50 \mu \mathrm{L}$ was solubilized in $5 \mathrm{~mL}$ of acetyl acetate and injected in to the split mode $1 / 100$.

2.5. Component Identification. The identification of the volatile components was based on comparison of their mass 
TABLE 1: Chemical composition of oil and volatile the J. ribifolia (Pohl) Baill identified by GC/MS and HS-SPME-GC-MS.

\begin{tabular}{|c|c|c|c|c|c|c|c|c|c|}
\hline & & Compounds ${ }^{\mathrm{a}}$ & $\mathrm{KI}^{\mathrm{b}}$ & $\mathrm{KI}^{\mathrm{c}}$ & Oil & $\mathrm{PA}$ & PDMS/DVB & PDMS & $\mathrm{CW} / \mathrm{DVB}$ \\
\hline 1 & 7.83 & Tricyclene & 919 & 921 & 3.79 & 7.52 & 32.39 & 21.01 & 12.26 \\
\hline 2 & 8.24 & $\alpha$-Pinene & 931 & 932 & 6.35 & 13.19 & $\mathrm{ND}$ & 21.32 & 15.22 \\
\hline 3 & 8.70 & Camphene & 945 & 946 & 4.34 & 8.65 & 11.98 & 15.15 & 23.65 \\
\hline 4 & 9.13 & 2,3,4-Trimethyl-2-cyclopenten-1-one & 958 & ND & $\mathrm{ND}$ & 0.01 & ND & ND & 3.20 \\
\hline 5 & 9.67 & $\beta$-Pinene & 974 & 974 & 9.16 & 18.26 & 19.48 & 22.3 & 4.45 \\
\hline 6 & 10.21 & $\beta$-Myrcene & 990 & 988 & 0.51 & 1.37 & 3.71 & 2.63 & 0.5 \\
\hline 7 & 10.81 & $\alpha$-Phellandrene & 994 & 1002 & $\mathrm{ND}$ & $\mathrm{ND}$ & 0.13 & 0.67 & 0.01 \\
\hline 8 & 11.06 & $\alpha$-Terpinen & 1014 & 1014 & 0.12 & 0.15 & 1.25 & 0.01 & 1.01 \\
\hline 9 & 11.35 & p-Cymene & 1022 & 1022 & 0.12 & 0.32 & 3.06 & 0.02 & 0.02 \\
\hline 10 & 11.47 & $d$-Limonene & 1026 & 1024 & 1.55 & 4.19 & 6.00 & 6.33 & 10.4 \\
\hline 11 & 12.32 & 3-Carene & 1057 & 1054 & $\mathrm{ND}$ & ND & 0.02 & 0.01 & ND \\
\hline 12 & 12.57 & $t$-Terpinene & 1057 & 1054 & 0.34 & 0.87 & 2.2 & 1.16 & 2.4 \\
\hline 13 & 13.05 & Trans-p-mentha-2,8-dienol & 1070 & $\mathrm{ND}$ & ND & 0.10 & 0.17 & 0.07 & 0.17 \\
\hline 14 & 13.63 & Terpinolene & 1088 & 1086 & 0.41 & 1.23 & 2.27 & 1.00 & 2.56 \\
\hline 15 & 14.12 & Linalool & 1100 & 1095 & 0.33 & 0.82 & 0.44 & 0.17 & 0.59 \\
\hline 16 & 14.54 & exo-fenchol & 1112 & 1116 & 0.42 & 0.9 & 0.6 & 0.25 & 0.91 \\
\hline 17 & 14.68 & Thujone & 1116 & 1114 & 0.05 & ND & 0.01 & 0.01 & 0.01 \\
\hline 18 & 14.83 & cis- $\beta$-terpineol & 1120 & 1130 & 0.05 & 0.18 & 0.01 & 0.01 & ND \\
\hline 19 & 14.99 & $\langle\alpha-\rangle$ campholenal & 1125 & 1126 & 0.03 & ND & 0.01 & 0.02 & 0.03 \\
\hline 20 & 15.41 & Trans-pinocarveol & 1137 & 1135 & 0.03 & 0.01 & 0.01 & 0.02 & 0.02 \\
\hline 21 & 15.62 & (-)-Camphor & 1142 & 1141 & 0.03 & 0.01 & 0.4 & 0.24 & 0.01 \\
\hline 22 & 15.76 & 2,3,3-Timethyl 2-norbornanol & 1147 & 1140 & 0.05 & 1.27 & ND & 0.36 & 1.2 \\
\hline 23 & 16.20 & Pinocamphone & 1159 & 1158 & $\mathrm{ND}$ & ND & $\mathrm{ND}$ & ND & 0.02 \\
\hline 24 & 16.36 & Borneol & 1164 & 1165 & 0.76 & 1.19 & 0.59 & 0.024 & 0.5 \\
\hline 25 & 16.69 & 3-Pinanone & 1173 & 1172 & 0.06 & ND & 0.05 & ND & 0.77 \\
\hline 26 & 16.80 & $p$ - Menth-1-en-4-ol, (R)-(-)- & 1176 & 1174 & 2.91 & 6.17 & 2.8 & 1.14 & 3.83 \\
\hline 27 & 17.29 & p-Menth-1-en-8-ol & 1185 & 1179 & 5.24 & 7.95 & 2.39 & 0.92 & 3.43 \\
\hline 28 & 17.96 & D-verbenone & 1209 & 1204 & ND & 0.04 & ND & ND & 0.03 \\
\hline 29 & 18.79 & $\begin{array}{l}\text { 1,3,3-Trimethyl-2-(2-methyl-cyclopropyl)- } \\
\text { cyclohexene) }\end{array}$ & 1190 & 1186 & ND & ND & 0.09 & 0.03 & 0.02 \\
\hline 30 & 20.55 & 2,6-Octadienoic acid, 3,7-dimethyl-, ethyl ester & 1195 & 1194 & 0.36 & 0.61 & 0.32 & 0.12 & 0.01 \\
\hline 31 & 20.94 & $\begin{array}{l}\text { Cyclopropane, } \\
\text { Trimethy(2-methyl-1-propenylidene)- }\end{array}$ & 1285 & $\mathrm{ND}$ & 1.23 & 2.06 & 0.82 & 0.3 & 1.05 \\
\hline 32 & 21.83 & Methyl geranate & 1296 & 1322 & 0.46 & 0.60 & 0.18 & 0.07 & 0.22 \\
\hline 33 & 22.75 & 2,4-Diisocyanato-1-methylbenzene & 1301 & ND & ND & 0.38 & ND & ND & ND \\
\hline 34 & 23.04 & Isolongifolene, 9,10-dehydro- & 1361 & $\mathrm{ND}$ & 0.12 & $\mathrm{ND}$ & 0.07 & 0.03 & 0.05 \\
\hline 35 & 23.43 & $\beta$-Vatirene & 1312 & $\mathrm{ND}$ & 8.34 & ND & 0.13 & 0.02 & 0.02 \\
\hline 36 & 23.59 & $\beta$-Patchoulene & 1324 & 1322 & 0.26 & 0.27 & 0.02 & 0.01 & 0.15 \\
\hline 37 & 24.05 & $\beta$-Elemene-(-) & 1361 & 1391 & 0.01 & 0.13 & 0.05 & 0.02 & 0.05 \\
\hline 38 & 24.30 & Cyperene & 1373 & 1398 & 0.01 & 6.45 & 2.72 & 1.19 & 3.35 \\
\hline 39 & 24.46 & (6-Hydroxymethyl-2,3-dimethylphenyl) methanol & 1378 & 1379 & ND & 0.01 & ND & ND & ND \\
\hline 40 & 24.77 & Isoledene & 1393 & 1389 & 1.35 & 0.89 & 0.36 & 0.14 & 0.44 \\
\hline 41 & 26.6 & $\alpha$-Gurjunene & 1400 & 1409 & 6.98 & 3.05 & 0.93 & 0.34 & 1.18 \\
\hline 42 & 27.36 & Isoeugenol methylether & 1494 & $\mathrm{ND}$ & 8.54 & 2.41 & 0.4 & 0.22 & ND \\
\hline 43 & 28.23 & Spathulenol & 1514 & 1490 & 0.74 & $\mathrm{ND}$ & $\mathrm{ND}$ & $\mathrm{ND}$ & 0.09 \\
\hline
\end{tabular}


TABle 1: Continued.

\begin{tabular}{|c|c|c|c|c|c|c|c|c|c|}
\hline & & Compounds $^{\mathrm{a}}$ & $\mathrm{KI}^{\mathrm{b}}$ & $\mathrm{KI}^{\mathrm{c}}$ & Oil & $\mathrm{PA}$ & PDMS/DVB & PDMS & $\mathrm{CW} / \mathrm{DVB}$ \\
\hline 44 & 28.87 & Aromadendrene, dehydro- & 1519 & ND & 3.52 & 0.93 & 0.22 & 0.11 & 0.32 \\
\hline 45 & 28.38 & Corimbolone & 1533 & ND & 0.01 & ND & ND & $\mathrm{ND}$ & ND \\
\hline 46 & 29.72 & isolongifolene-5-ol & 1534 & ND & 0.65 & ND & ND & ND & ND \\
\hline 47 & 30.52 & $\begin{array}{l}\text { 4,4,11,11-Tetramethyl-7-tetracyclo } \\
{[6.2 \cdot 1.0(3.8) 0(3.9)] \text { undecanol }}\end{array}$ & 1608 & ND & 6.64 & 0.39 & 0.15 & 0.14 & ND \\
\hline 48 & 30.83 & Cedrol & 1619 & ND & 0.01 & ND & ND & ND & ND \\
\hline 49 & 30.91 & $\begin{array}{l}\text { 8S-cis-5(1H)-Azulenone, } 2,4,6,7,8,8 \mathrm{a} \text {-hexahydro- } \\
\text { 3,8-dimethyl-4-(1-methylethylidene) }\end{array}$ & 1622 & ND & 3.33 & ND & ND & ND & ND \\
\hline 50 & 31.55 & Tujopsanone $\langle 3-\rangle$ & 1645 & 1650 & 1.25 & ND & ND & ND & ND \\
\hline 51 & 32.0 & $\begin{array}{l}\text { 4a,8,8-Trimethyloctahydro } \\
\text { cyclopropa(d)naphthalen-2(3H)-one }\end{array}$ & 1661 & ND & 0.01 & ND & ND & ND & ND \\
\hline 52 & 32.34 & (-)-Spathulenol & 1673 & ND & 1.25 & ND & $\mathrm{ND}$ & $\mathrm{ND}$ & ND \\
\hline 53 & 32.69 & $\begin{array}{l}\text { 6-Isopropenyl-4,8a-dimethyl-1,2,3,5,6,7,8,8a- } \\
\text { octahydro-naphthalen-2-ol }\end{array}$ & 1696 & ND & 1.15 & ND & ND & ND & ND \\
\hline 54 & 32.90 & $\beta$-Guaiene & 1697 & ND & 0.02 & ND & ND & $\mathrm{ND}$ & ND \\
\hline 55 & 33.41 & $\begin{array}{l}\text { 2,2,7,7-Tetramethyltricyclo } \\
{[6 \cdot 2 \cdot 1 \cdot 0(1,6)] \text { undec-4-en-3-one }}\end{array}$ & 1713 & ND & 0.46 & ND & ND & ND & ND \\
\hline 56 & 33,92 & $\begin{array}{l}\text { 2(1H)naphthalenone, } 3,5,6,7,8,8 \mathrm{a} \text {-hexahydro- } 4,8 \mathrm{a}- \\
\text { dimethyl-6-(1-methylethenyl) }\end{array}$ & 1732 & ND & 1.15 & ND & ND & ND & ND \\
\hline 57 & 34.12 & $\begin{array}{l}\text { Acetic acid, 7-isoprophenyl-1,4a-dimethyl-3-oxo- } \\
\text { 2,3,4,4a,5,6,7,8-octahydronaphthalen-2-il } \\
\text { esther }\end{array}$ & 1740 & ND & 0.09 & ND & ND & ND & ND \\
\hline 58 & 34.16 & Oxide-[2] aromadendrene & 1762 & ND & 0.01 & ND & ND & ND & ND \\
\hline 59 & 34.78 & 8-Oxо-9H-cycloisolongipholene & 1765 & ND & 2.09 & $\mathrm{ND}$ & ND & $\mathrm{ND}$ & ND \\
\hline 60 & 35.08 & Valeral & 1776 & ND & 0.41 & ND & ND & ND & ND \\
\hline \multirow[t]{6}{*}{61} & 35.94 & Methyl hinokiate & 1827 & ND & 1.20 & ND & ND & ND & ND \\
\hline & & \multicolumn{2}{|l|}{ Total (\%) } & & 87.06 & 92.58 & 96.43 & 97.58 & 94.15 \\
\hline & & \multicolumn{2}{|l|}{ Terpenes } & & 48.51 & 69.53 & 87.9 & 93.8 & 79.11 \\
\hline & & \multicolumn{2}{|l|}{ Alcohols/aldehyde } & & 19.66 & 18.99 & 7.22 & 3.124 & 11.54 \\
\hline & & \multicolumn{2}{|l|}{ Ketone } & & 4.66 & 0.06 & 0.41 & 0.25 & 3.27 \\
\hline & & \multicolumn{2}{|l|}{ Others } & & 14.23 & 4.00 & 0.90 & 0.41 & 0.23 \\
\hline
\end{tabular}

RT: retention time; ND: not determined; ${ }^{a}$ compounds listed in order of elution from a DB- 5 column; ${ }^{b} \mathrm{KI}$ calculated; ${ }^{\mathrm{c}} \mathrm{KI}$ tabulated. PA: polyacrylate fiber; PDMS/DVB: polydimethylsiloxane/divinylbenzene fiber; PDMS: polydimethylsiloxane fiber; CW/DVB: Carbowax/divinylbenzene fiber.

spectra with those of NIST 2.0 and those described by Adams [31], as well as by comparison of their retention indexes with the literature data $[32,33]$ and by comparison of their retention times with those of pure authentic samples.

\section{Results and Discussion}

The roots of J. ribifolia were subjected to hydrodistillation for $4 \mathrm{~h}$ using a modified Clevenger-type apparatus, with a yield of the $0.09 \%$. The oil showed a green-bluish coloration with a powerful fragrance. To our knowledge, the volatile composition for essential oil of roots has not been shown for J. ribifolia in the literature. The complete composition for oil and volatiles was performed through the GC-MS and HS-SPME-GC-MS. The results are viewed in Table 1, where it shows the KI calculated and tabulated to all compounds and its percentage. The main terpenes present in the chemical composition of the root oil of J. ribifolia were $\beta$-pinene (9.16\%), $\beta$-vatirene (8.34\%), $\alpha$-gurjunene $(6.98 \%)$, $\alpha$-pinene $(6.35 \%)$, camphene $(4.34 \%)$, tricyclene $(3.79 \%)$, and dehydro aromadendrene (3.52\%). Alcohols, aldehydes, 


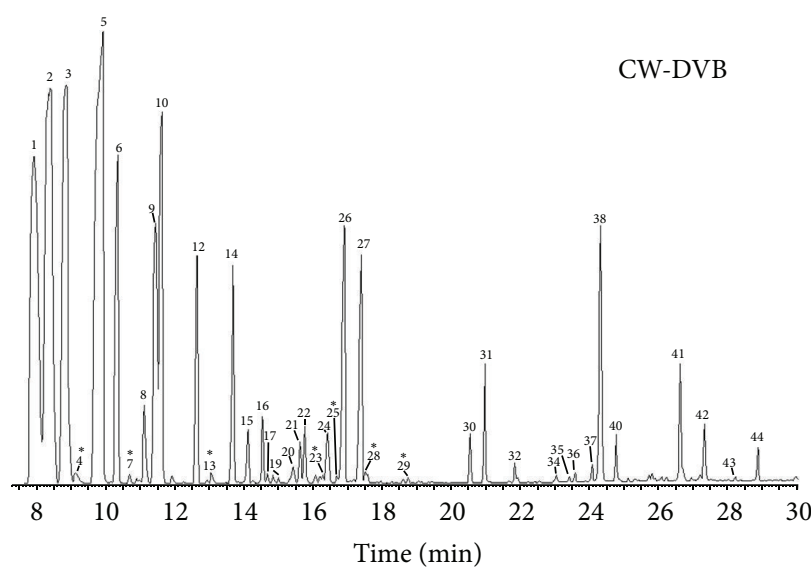

(a)

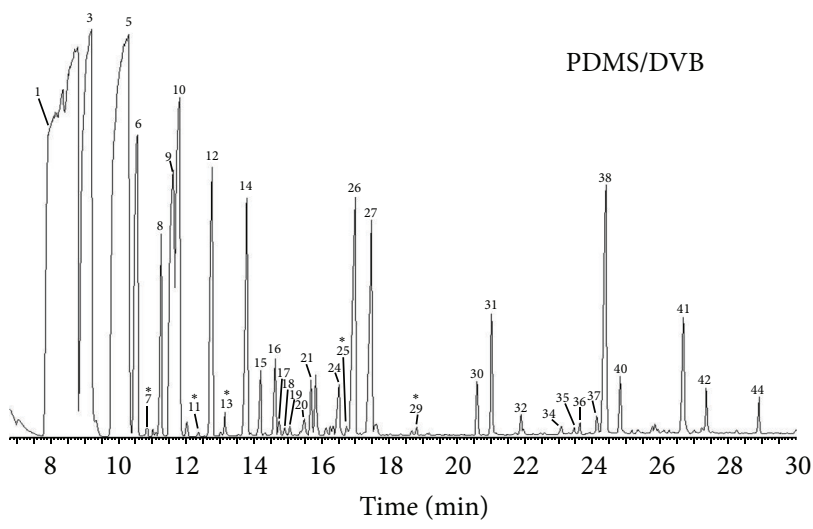

(c)

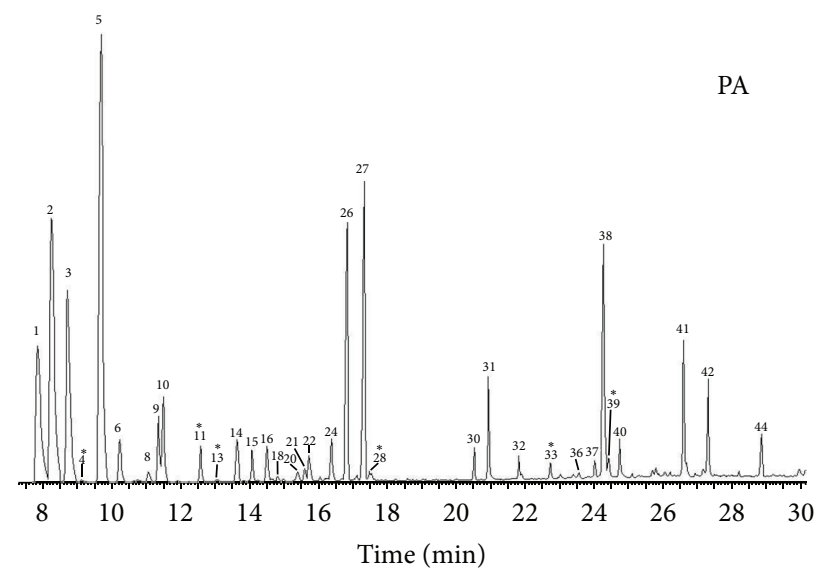

(b)

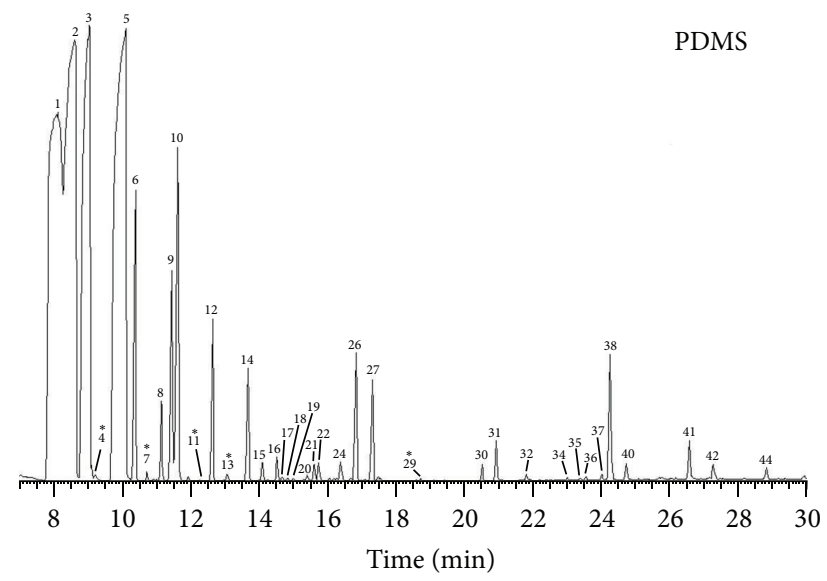

(d)

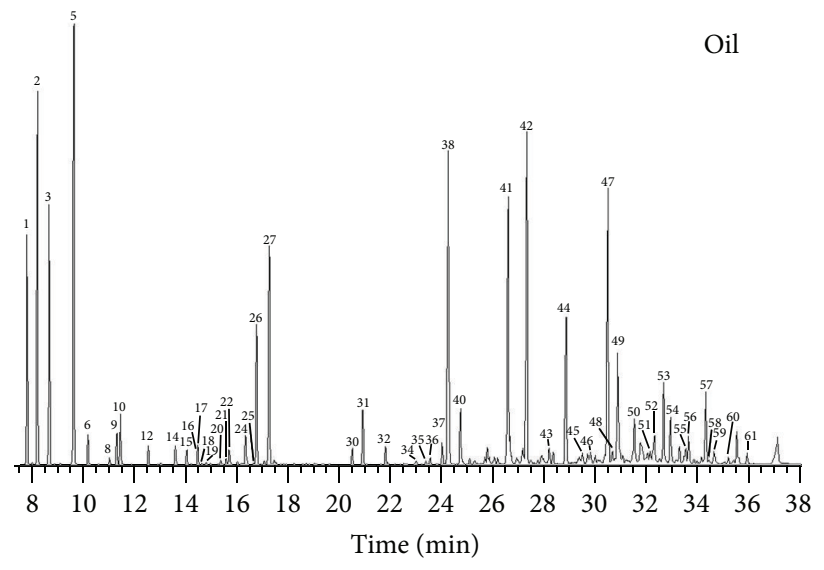

(e)

FIGURE 1: Typical total ion chromatograms (TIC) of J. ribifolia oil obtained by GC-MS and volatile compounds determined by HS-SPMEGC-MS * compounds identified only in volatile fraction of oil: (4) 2,3,4-trimethyl-2-cyclopenten-1-one, (7) $\alpha$-phellandrene; (11) 3-carene, (13) trans- $p$-mentha-2,8-dienol, (23) pinocamphone, (28) D-verbenon, (29) 1,3,3-trimethyl-2-(2-methyl-cyclopropyl)-cyclohexene, (33) 2,4diisocyanato-1-methylbenzene, and (39) (6-hydroxymethyl-2,3-dimethylphenyl) methanol.

and ketones represent an important fraction of the chemical composition of the oil, being the compounds $p$-menth1-en-8-ol (5.24\%), 8S-cis-5(1H)-azulenone, and 2.4.6.7.8.8ahexahydro-3.8-dimethyl-4-(1-methylethylidene) $(3.33 \%)$ the major components with these functional groups.
SPME is a technique of extraction not exhaustive [26], in which an optical fiber coated by sorbent/adsorbent materials is exposed to the headspace above the sample or where the fiber is immersed into the aqueous phase. The extraction of analytes can be attributed to their characteristics associated 


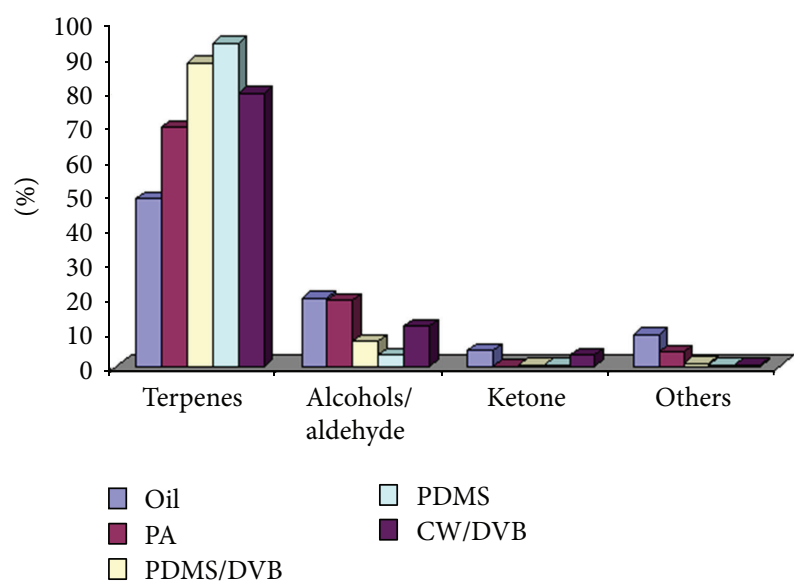

FIgUre 2: Percentage composition of the major chemical classes detected in the oil and by using different SPME fibers.

with the fiber coating. Fibers of nonpolar coatings such as PDMS are more suitable for the analysis of nonpolar compounds; PDMS/DVB (bipolar fiber) applied to volatile and nonvolatile low-to-high polarity and polyacrlate (PA) (polar fiber) the volatile compounds extraction of medium to high polarity $[22,34]$. For tools fibers the extraction time was short to avoid saturation of the coating of the fiber due to that the oil is highly volatile. Thus there was no saturation of the mass spectrometer detector. A total of sixty-one compounds were identified and compared with the retention KI for oil and volatile composition. The composition of oil evaluated was eighty-seven percent, while for the profile of volatiles it was performed with SPME fiber above ninety-two percent.

The chromatographic profile obtained from volatile oil with the PDMS and PDMS/DVB fibers were very similar at the beginning of chromatogram where for the tricyclene and $\alpha$-pinene compounds there was no good separation. The CW/DVB and PA generally showed better results in the extraction of low molecular weight compounds as well as for moderately heavy. The compounds of high molecular weight of the oil between 30 and 47 minutes not were extracted by SPME fibers due to the short extraction time or low volatility.

Through the use of SPME for the volatile extraction it was possible to identify the nine volatile compounds that were not identified by direct injection in GC-MS. These were the (4) 3,3,4-trimethy-2-cyclopentene-1-one, (7) $\alpha$-phellandrene; (11) 3-carene, (13) trans- $p$-mentha-2,8dienol, (23) pinocamphone, (28) D-verbenon, (29) 1,3,3trimethyl-2-(2-methyl-cyclopropyl)-cyclohexene, (33) 2,4diisocyanato-1-methylbenzene, and (39) (6-hydroxymethyl2,3-dimethylphenyl) methanol. The PA and CW/DVB fibers were selective to extraction of (23) pinocamphone, (33) 2,4-diisocyanato-1-methylbenzene, and (39) (6-hydroxymethyl-2,3-dimethylphenyl) methanol compounds appearing only in these chromatograms. Terpenes are in major concentration to all analyses followed by alcohols/aldehyde and ketones. Figure 2 shows better this preview.

Some compounds showed significant differences in the chemical composition of the oil and the chromatographic profile obtained with the fibers. As an example the case of compound $\tau$-terpinene can be observed. This component is with a low concentration in the oil, while, using the fibers (CW-DVB, PDMS-DVB, and PDMS), this terpene has a higher intensity in the chromatograms (Figure 1). With other monoterpenes such as limonene, $\beta$-pinene, $\alpha$-pinene, and camphene, among others, this fact also occurs. The compounds were identified by comparing their KI and by mass spectrum in accordance with the example (Figure 3).

\section{Conclusion}

The present study is the first report which describes the volatile chemical composition and essential oil of roots from J. ribifolia (Pohl) Baill performed by HS-SPME-GC-MS and GC-MS, respectively. Relative to the plant chemical composition, we conclude that the root's oil is mainly represented by terpenes, alcohols, and aldehyde compounds and that can be used in biological assay. SPME technique showed the profile of chemical composition of volatile to the essential oil. According to the obtained results, it is proposed that in studies involving SPME volatile oils are most effective and safe when fibers are employed with different characteristics, since they can provide different chromatographic profiles of raw oil. Through the analysis procedure performed, it is observed that the fibers were more efficient in extraction of monoterpene compounds meaningful distinction occurring profile obtained for oil and for the fibers obtained, as evidenced in the case of compounds like tricyclene, $\alpha$-pinene, camphene, $\beta$-pinene, and $\beta$-myrcene, with a major concentration in the chromatographic profile in SPME fibers. In the case of sesquiterpenes, the raw oil presented a higher concentration of these compounds also showing discrepancy between the profiles of the oil and the fibers used for the analyses. Sesquiterpenes, such as $\beta$-vatirene, $\alpha$-gurjunene, spathulenol, dehydro-aromadendrene, 6-isopropenyl-4,8adimethyl-1,2,3,5,6,7,8,8a-octahydro-naphthalen-2-ol, and 8oxo-9H-cycloisolongifolene, were significantly more abundant in the chromatographic profile of raw oil. Besides these observations some compounds present the oil in concentrations low (trace levels) which hampered their identification in some SPME fibers. As an example the 6Isopropenyl-4,8a-dimethyl-1,2,3,5,6,7,8,8a-octahydro-naphthalen-2-ol sesquiterpene with content of $6.64 \%$ in oil not was detected by CW/DVB fiber. The same occurs with the phenylpropanoid isoeugenol methylether with a content of $8.54 \%$ in oil.

Due to the possible biological activities for the oil, further studies are in progress in our laboratory to confirm the antiproliferative activity of this plant. 


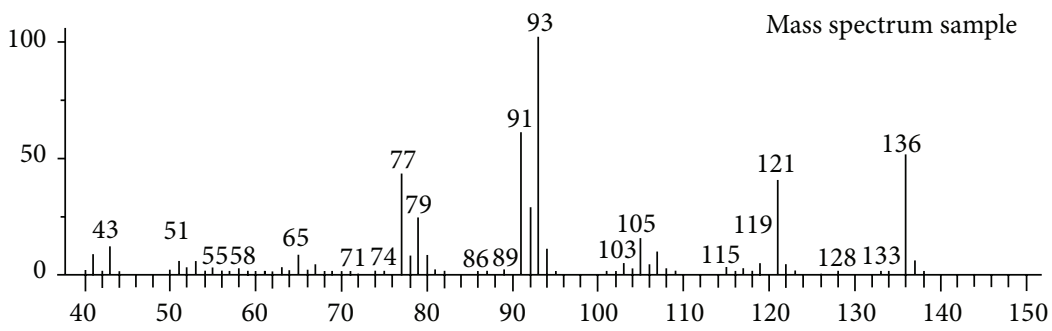

(a)

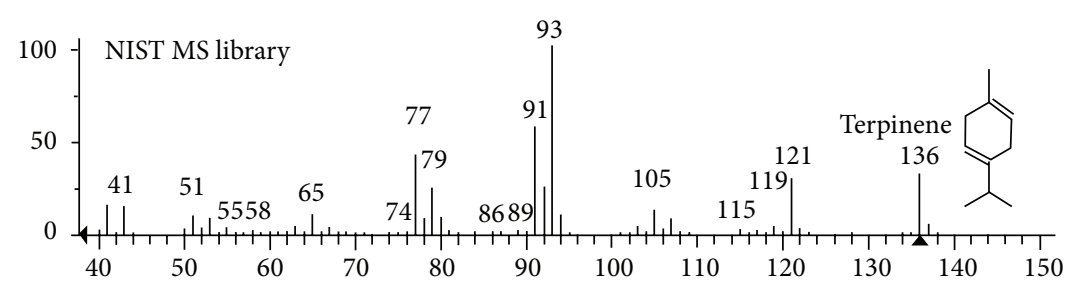

(b)

FIGURE 3: Mass spectrum for $\tau$-terpinene obtained from the volatile fraction of the oil by SPME fiber PDMS/DVB and compared to the spectrum of the NIST MS library. Retention time $12.57 \mathrm{~min}$.

\section{Acknowledgments}

The authors are grateful to Dr. Willian F. Costa and the University of Maringá (UEM) for the chemical analysis and Fundect-MS for financial support.

\section{References}

[1] L. A. Pimentel, B. Riet-Correa, A. F. Dantas, R. M. T. Medeiros, and F. Riet-Correa, "Poisoning by Jatropha ribifolia in goats," Toxicon, vol. 59, no. 5, pp. 587-591, 2012.

[2] E. S. Fernandes, F. A. Rodrigues, D. Tófoli et al., "Isolation structural identification and cytotoxic activity of hexanic extract, cyperenoic acid, and jatrophone terpenes from Jatropha ribifolia (Pohl) Baill roots," Journal of Pharmacy and Pharmacognosy, vol. 23, no. 3, pp. 441-446, 2013.

[3] E. L. Neves, L. S. Funch, and B. F. Viana, "Comportamento fenológico de três espécies de Jatropha(Euphorbiaceae) da Caatinga, semi-árido do Brasil," Revista Brasileira de Botanica, vol. 33, no. 1, pp. 155-166, 2010.

[4] F. Deeba, V. Kumar, K. Gautam, R. K. Saxena, and D. K. Sharma, "Bioprocessing of Jatropha curcas seed oil and deoiled seed hulls for the production of biodiesel and biogas," Biomass and Bioenergy, vol. 40, pp. 13-18, 2012.

[5] K. F. Yee, K. T. Lee, R. Ceccato, and A. Z. Abdullah, "Production of biodiesel from Jatropha curcas L. oil catalyzed by $\mathrm{SO}_{4}^{2-} / \mathrm{ZrO} 2$ catalyst: effect of interaction between process variables," Bioresource Technology, vol. 102, no. 5, pp. 4285-4289, 2011.

[6] G. Corro, N. Tellez, E. Ayala, and A. Marinez-Ayala, "Twostep biodiesel production from Jatropha curcas crude oil using $\mathrm{SiO}_{2} \cdot \mathrm{HF}$ solid catalyst for FFA esterification step," Fuel, vol. 89, no. 10, pp. 2815-2821, 2010.

[7] S. R. Mariz, M. S. T. Araújo, G. S. Cerqueira et al., "Avaliação histopatológica em ratos após tratamento agudo com extrato etanólico de partes aéreas de Jatropha gossypfolia L.," Brazilian Journal of Pharmacognosy, vol. 18, pp. 213-216, 2008.
[8] V. P. Kumar, N. S. Chauhan, H. Padh, and M. Rajani, "Search for antibacterial and antifungal agents from selected Indian medicinal plants," Journal of Ethnopharmacology, vol. 107, no. 2, pp. 182-188, 2006.

[9] R. K. Devappa, H. P. S. Makkar, and K. Becker, "Biodegradation of Jatropha curcas phorbol esters in soil," Journal of the Science of Food and Agriculture, vol. 90, no. 12, pp. 2090-2097, 2010.

[10] R. K. Devappa, S. K. Rajesh, V. Kumar, H. P. S. Makkar, and K. Becker, "Activities of Jatropha curcas phorbol esters in various bioassays," Ecotoxicology and Environmental Safety, vol. 78, pp. $57-62,2012$.

[11] N. Narain, M. D. S. Galvão, and M. S. Madruga, "Volatile compounds captured through purge and trap technique in cajaumbu (Spondias sp.) fruits during maturation," Food Chemistry, vol. 102, no. 3, pp. 726-731, 2007.

[12] S. Moret, L. Barp, K. Grob, and L. S. Conte, "Optimised offline SPE-GC-FID method for the determination of Mineral Oil Saturated Hydrocarbons (MOSH) in vegetable oils," Food Chemistry, vol. 129, no. 4, pp. 1898-1903, 2011.

[13] J. Paolini, C. Leandri, J.-M. Desjobert, T. Barboni, and J. Costa, "Comparison of liquid-liquid extraction with headspace methods for the characterization of volatile fractions of commercial hydrolats from typically Mediterranean species," Journal of Chromatography A, vol. 1193, no. 1-2, pp. 37-49, 2008.

[14] C. W. Sabandar, N. J. Ahmat, and I. Sahidin, "Medicinal property, phytochemistry and pharmacology of several Jatropha species (Euphorbiaceae): a review," Phtochemistry, vol. 85, pp. 729, 2013.

[15] M.-T. Golmakani and K. Rezaei, "Comparison of microwaveassisted hydrodistillation withthe traditional hydrodistillation method in the extractionof essential oils from Thymus vulgaris L," Food Chemistry, vol. 109, no. 4, pp. 925-930, 2008.

[16] M. A. Ferhat, B. Y. Meklati, J. Smadja, and F. Chemat, "An improved microwave Clevenger apparatus for distillation of essential oils from orange peel," Journal of Chromatography A, vol. 1112, no. 1-2, pp. 121-126, 2006. 
[17] S. M. Pourmortazavi and S. S. Hajimirsadeghi, "Supercritical fluid extraction in plant essential and volatile oil analysis," Journal of Chromatography A, vol. 1163, no. 1-2, pp. 2-24, 2007.

[18] B. Benyelles, H. Allali, M. El Amine Dib, N. Djabou, B. Tabti, and J. Costa, "Essential oil from Rhaponticum acaule L. roots: comparative study using HS-SPME/GC/GC-MS and hydrodistillation techniques," Journal of Saudi Chemical Society, 2011.

[19] B. Huang, Y. Lei, Y. Tang, J. Zhang, L. Qin, and J. Liu, "Comparison of HS-SPME with hydrodistillation and SFE for the analysis of the volatile compounds of Zisu and Baisu, two varietal species of Perilla frutescens of Chinese origin," Food Chemistry, vol. 125, no. 1, pp. 268-275, 2011.

[20] F. Ahmadi, S. Sadeghi, M. Modarresi, R. Abiri, and A. Mikaeli, "Chemical composition, in vitro anti-microbial, antifungal and antioxidant activities of the essential oil and methanolic extract of Hymenocrater longiflorus Benth., of Iran," Food and Chemical Toxicology, vol. 48, no. 5, pp. 1137-1144, 2010.

[21] J. Wu and $\mathrm{H}$. K. Lee, "Injection port derivatization following ion-pair hollow fiber-protected liquid-phase microextraction for determining acidic herbicides by gas chromatography/mass spectrometry," Analytical Chemistry, vol. 78, no. 20, pp. 72927301, 2006.

[22] F. Augusto and A. L. Valente, "Microextração por fase sólida," Química Nova, vol. 23, no. 4, pp. 523-530, 2000.

[23] R. C. Silva, E. C. Meurer, M. N. Eberlin, and F. Augusto, "Determination of phthalates in water using fiber introduction mass spectrometry," Analyst, vol. 130, no. 2, pp. 188-192, 2005.

[24] F. Augusto, J. Koziel, and J. Pawliszyn, "Design and validation of portable SPME devices for rapid field air sampling and diffusion-based calibration," Analytical Chemistry, vol. 73, no. 3, pp. 481-486, 2001.

[25] J. Castro, R. A. Pérez, C. Sánchez-Brunete, and J. L. Tadeo, "Analysis of pesticides volatilised from plants and soil by headspace solid-phase microextraction and gas chromatography," Chromatographia, vol. 53, supplement 1, pp. S361-S365, 2001.

[26] C. L. Artur and J. Pawliszyn, "Solid phase microextraction with thermal desorption using fused silica optical fibers," Analytical Chemistry, vol. 62, no. 19, pp. 2145-2148, 1990.

[27] R. C. Silva, P. M. S. Aguiar, and F. Augusto, "Coupling of dynamic headspace sampling and solid phase microextraction," Chromatographia, vol. 60, no. 11-12, pp. 687-691, 2004.

[28] E. H. M. Koster, C. Wemes, J. B. Morsink, and G. J. de Jong, "Determination of lidocaine in plasma by direct solid-phase microextraction combined with gas chromatography," Journal of Chromatography B, vol. 739, no. 1, pp. 175-182, 2000.

[29] E. C. Meurer, D. M. Tomazela, R. C. Silva, F. Augusto, and M. N. Eberlin, "Fiber introduction mass spectrometry: fully direct coupling of solid-phase microextraction with mass spectrometry," Analytical Chemistry, vol. 74, no. 21, pp. 5688-5692, 2002.

[30] M. N. Eberlin and R. Cesar da Silva, "Faster and simpler determination of chlorophenols in water by fiber introduction mass spectrometry," Analytica Chimica Acta, vol. 620, no. 1-2, pp. 97-102, 2008.

[31] R. P. Adams, Identification of Essential Oil Components by Gas Chromatography/Quadrupole Mass Spectroscopy, Allured, Carol Stream, Ill, USA, 2001.

[32] W. Jennings and T. Shibamoto, Qualitative Analysis of Flavour and Fragrance Volatiles by Glass-Capillary Gas Chromatography, Academic Press, New York, NY, USA, 1980.
[33] National Institute of Standards Technology, PC Version 1.7 of the NIST/EPA/NIH Mass Spectral Library, Perkin Elmer Corporation, Norwalk, Conn, USA, 1999.

[34] E. Coelho, C. Ferreira, and C. M. M. Almeida, "Analysis of polynuclear aromatic hydrocarbons by SPME-GC-FID in environmental and tap waters," Journal of the Brazilian Chemical Society, vol. 19, no. 6, pp. 1084-1097, 2008. 

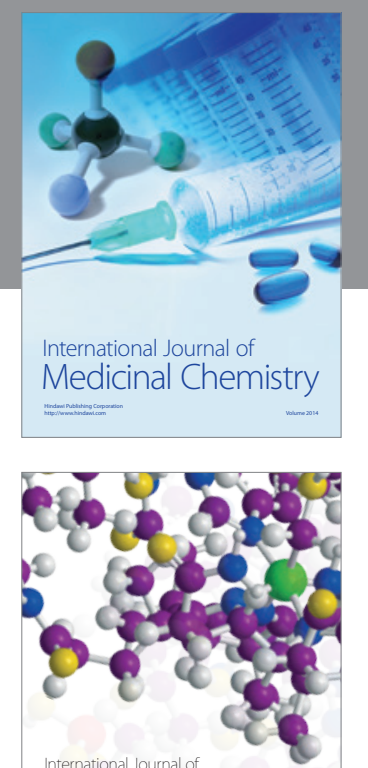

\section{Carbohydrate} Chemistry

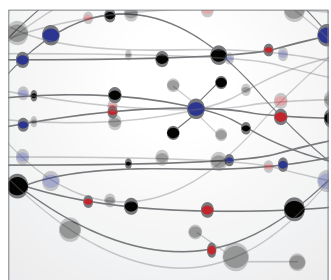

The Scientific World Journal
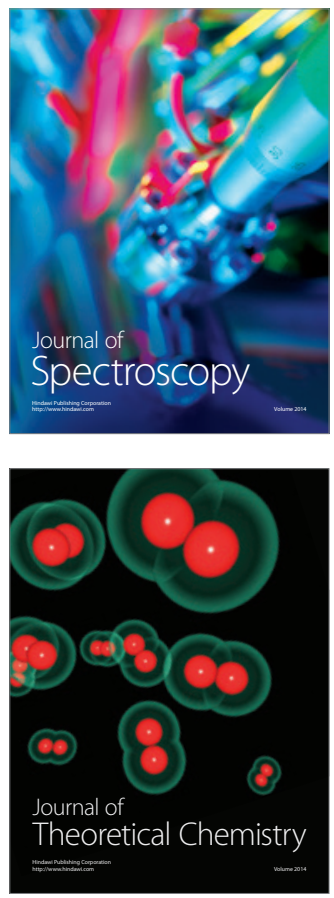
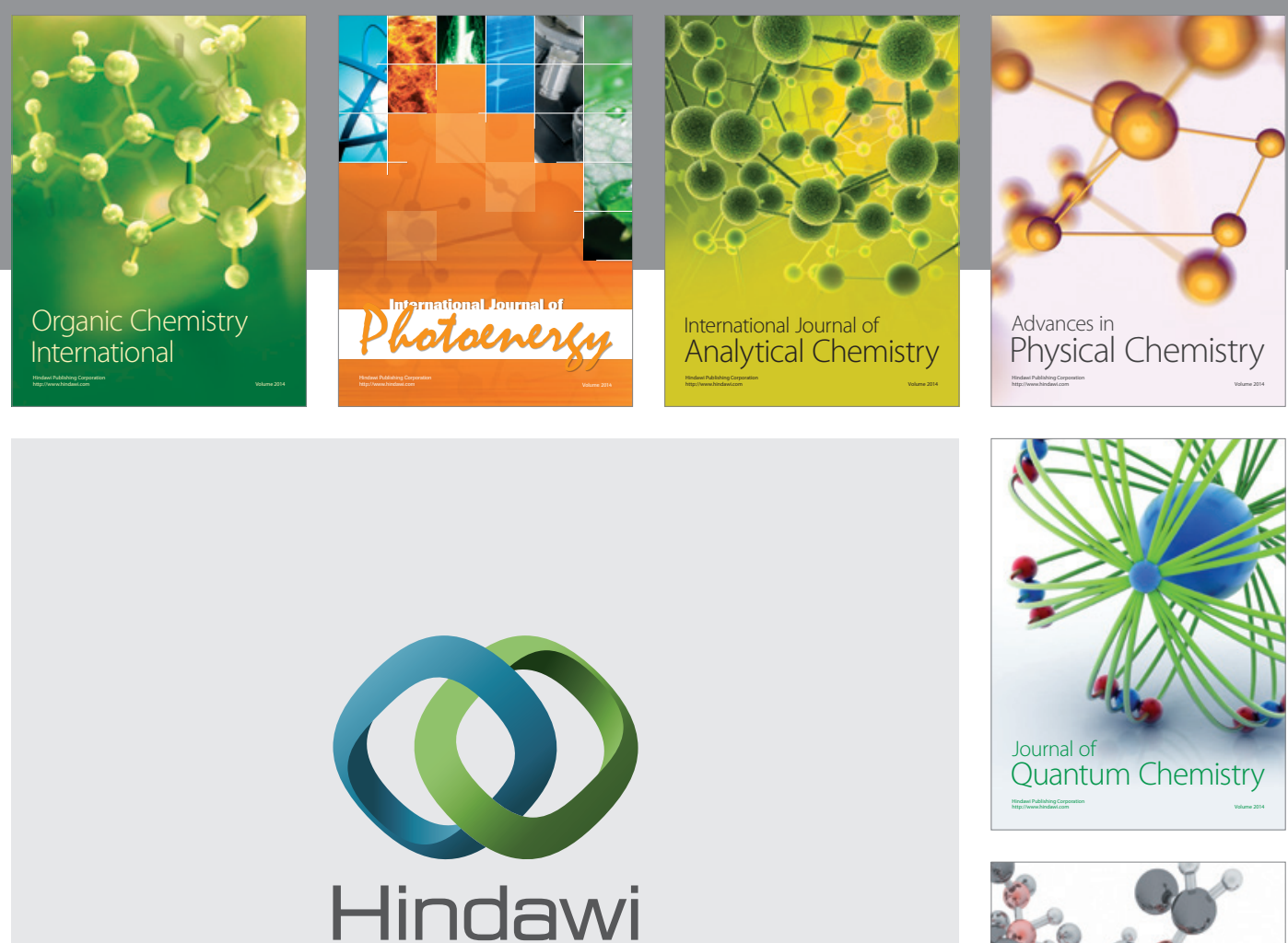

Submit your manuscripts at

http://www.hindawi.com

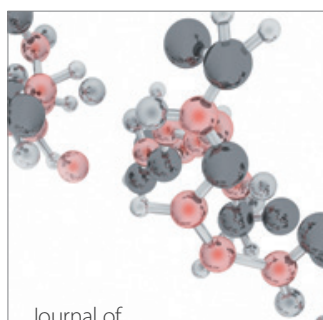

Analytical Methods

in Chemistry

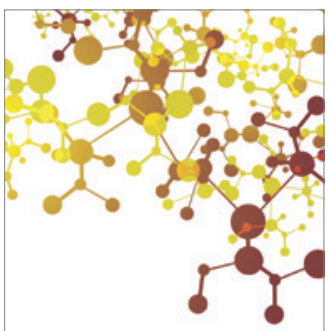

Journal of

Applied Chemistry

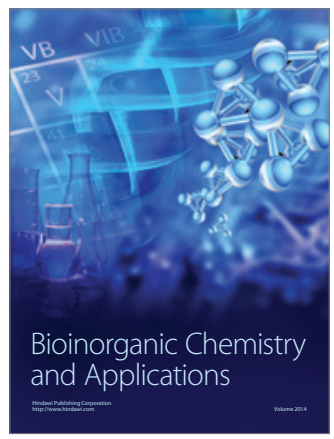

Inorganic Chemistry
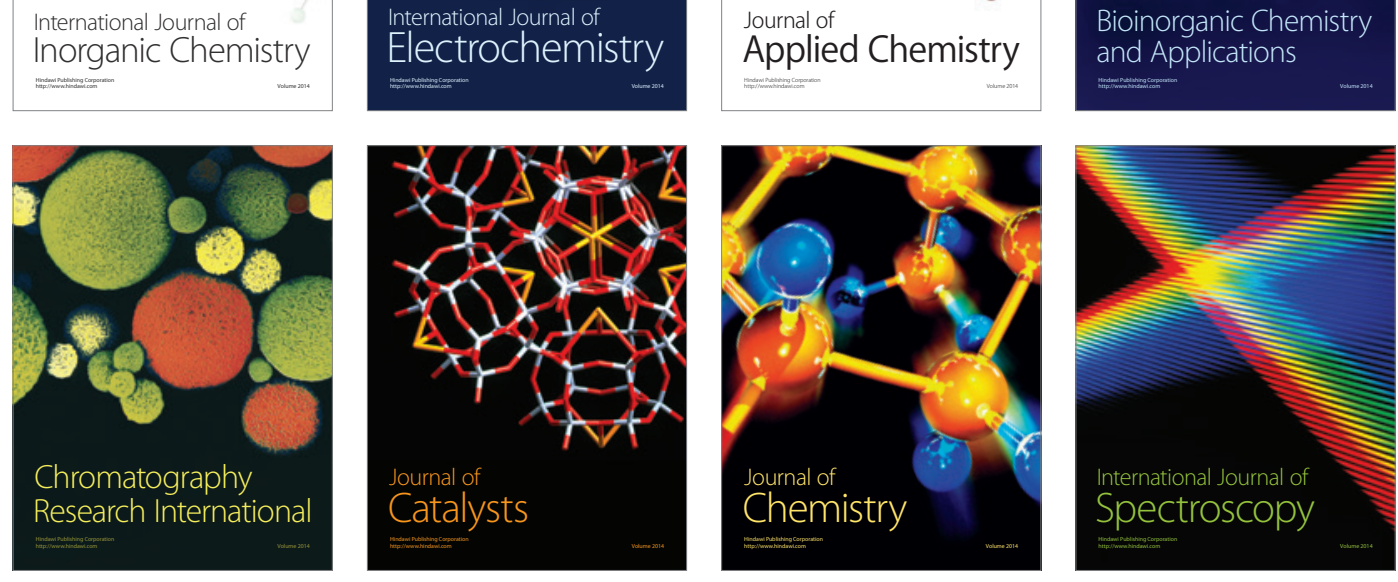